\title{
Eurázijské kultúrne kontexty slovenskej l’udovej čarodejnej rozprávky
}

\author{
Lukáš Šutor \\ Katedra slovakistiky, slovanských filológií a komunikácie, Filozofická fakulta, Univerzita Pavla Jozefa Šafárika v Košiciach, \\ Šrobárova 2, 04059 Košice, Slovenská republika
}

Do redakce doručeno 10. února 2021; k publikaci přijato 6. dubna 2021

\section{EURASIAN CULTURAL CONTEXTS OF SLOVAK FOLK MAGIC TALE}

ABSTRACT The study contains an analysis and interpretation of Slovak folk magic tale material in a cultural-anthropological context (with emphasis on the Anthropology of Art, Anthropology of Religion and Symbolic Anthropology). The material includes the most important collections with a predominance of magical tales from representative collections of the 19th century in Slovakia (pre-romantic, romantic and post-romantic school). We draw attention to the worldview and value antagonism of two cultural complexes (Agrarian and Nomadic) in the Eurasian region and their transformation into a story conflict of the respective symbolic forms in the observed magic tales and their type variants. The core of the story activity is the initiation of a wizard / shaman, which in its described form can be deduced from the prevalence of spiritual ideas of the nomadic cultural complex with an affinity for the symbols of the uranus circle. We consider Central Asia to be the most probable center of the dominant ideological forms of the observed magic tales.

KEY WORDS folk magic tales; Anthropology of Art; Anthropology of Religion; shamanism

ABSTRAKT Štúdia obsahuje analýzu a interpretáciu slovenského rozprávkového materiálu v kultúrno-antropologickom kontexte (s dôrazom na antropológiu umenia, antropológiu náboženstva a symbolickú antropológiu). Materiál zahŕňa najdôležitejšie zbierky s prevahou čarodejných rozprávok z reprezentatívnych zberov 19. storočia na Slovensku (preromantická, romantická a postromantická škola). Upozorňujeme na svetonázorový a hodnotový antagonizmus dvoch kultúrnych komplexov (agrárneho a nomádskeho) v eurázijskom regióne a ich pretavenia do príbehového konfliktu prislúchajúcich symbolických foriem v sledovaných rozprávkach a ich typových variantoch. Jadrom príbehovej aktivity je iniciácia čarodejníka/šamana, ktorá je v opisovanej podobe odvoditelná z prevalencie duchovných predstáv nomádskeho kultúrneho komplexu s afinitou na symboly uranovského okruhu. Za najpravdepodobnejšie centrum dominantných ideových foriem sledovaných rozprávkových príbehov považujeme Strednú Áziu.

KL'ÚČOVÉ SLOVÁ čarodejná rozprávka; antropológia umenia; antropológia náboženstva; šamanizmus

Ked’ sme v minulom príspevku (2018) predstavili širokú antropologickú perspektívu výskumu ludových čarodejných rozprávok, museli sme pristúpit' na pluralitný obraz tohto fenoménu, ktorý závisel nielen od pestrého empirického materiálu, ale najmä od jeho vyhodnotenia jednotlivými školami a bádatelmi. Antropologický pohlad na túto problematiku má však nespornú výhodu, ponúka totiž súbor invariantných znakov globálneho žánru čarodejnej rozprávky, ktorý tvorí dôležitú základňu pri vyhodnocovaní lokálnych kultúrnych osobitostí.
Pri aktuálnej analýze a interpretácii vychádzame najmä z faktu, že sledované typy príbehov vznikali v konkrétnych kultúrnych kontextoch a že boli v týchto systémoch napojené na špecifické ideové štruktúry. Výber slovenského materiálu ${ }^{1}$ má dva hlavné dôvody. Po prvé si analyzovaný materiál zachováva archaické črty a po druhé je to materiál, ktorý

1 Zbierky s prevahou ludových čarodejných rozprávok, s ktorým sme pracovali, uvádzame v prameňoch. Súhrne predstavujú materiál najreprezentatívnejších zberov 19. storočia z územia Slovenska. 
pars pro toto zastupuje východné a západné folklórne látky prítomné v celej Eurázii, ktorej kultúrny kontext pri výskume musíme brat do úvahy. Za mnohé príklady, uvádzané v štúdii, by sme mohli dosadit aj český rozprávkový materiál. V slovenských čarodejných rozprávkach sú výrazne prítomné ideové štruktúry dvoch príbehovo konkurenčných $k u l-$ túrnych komplexov. ${ }^{2}$

1. Vzhladom na sociálno-kultúrny kontext, v ktorom boli slovenské rozprávky zapísané ako živé príbehy (najmä 19. storočie), je možno prekvapujúce konštatovanie, že obsahujú malé množstvo agrárnych prvkov. Toto tvrdenie sa budeme snažit dokázat' na viacerých úrovniach príbehov. V tematickej štruktúre nachádzame len málo motívov, ktoré patria do okruhu polnohospodárskeho života: obrábanie pôdy, hospodárske zvieratá, činnosti vztahujúce sa na spracovanie obilia a živočíšnych produktov, priestorovú štruktúru agrárnej komunity a s tým súvisiacu spoločenskú organizáciu. Tematický mimetizmus kultúrnych reálií je síce zaujímavý a rýchlo prístupný, sám o sebe však v argumentácii nestačí. Motívy, ktoré sme identifikovali ako agrárne, musíme d’alej analyzovat pozične $\mathrm{v}$ celom príbehu. $\mathrm{Z}$ tejto hlbšej perspektívy sa ukazuje, že agrárne motívy sú prítomné najmä v mladších príbehových variantoch, a to ako neskoršie segmenty, a patria medzi najčastejšie substitučné zložky motivického plánu. ${ }^{3} \mathrm{Z}$ kompozičného hladiska sú agrárne reálie najviac koncentrované v rámcových častiach, teda mimo príbehového jadra, ktoré je stabilnejšie. Konkrétny príbeh sa často skladá $\mathrm{z}$ viacerých - tradíciou od seba dobre rozoznatel'ných - sujetov ${ }^{4}$. Pri pohlade na celý príbeh majú sujety s výrazným agrárnym kultúrnym profilom rovnako okrajovú a substitučnú pozíciu ako sme konštatovali pri agrárnych motívoch.

Pri dalšom uvažovaní o agrárnom kultúrnom komplexe prítomnom $\mathrm{v}$ ludových čarodejných rozprávkach musíme opustit mimetické a tvarové hladiská a vstúpit do sféry významov estetických znakov. To, čo nám dovoluje uvažovat' o kultúrnych komplexoch ako o metaempirických konštruktoch, sú práve znakové systémy, spoločné pre podobné typy konkrétnych kultúr. Pre naše potreby ich môžeme zúžit' na duchovné systémy reprezentované sietou dialekticky pre-

2 Termín kultúrny komplex je teoretický konštrukt zahŕňajúci typovo príbuzné kultúry, ktoré majú podobné stratégie naplńnania základných potrieb (symptomaticky najmä spôsob obživy), príbuznú sociálnu štruktúru a porovnatel'né ideové a hodnotové systémy, ako sú svetonázorové a duchovné predstavy.

3 Znakom neskorších (mladších) motívov či celých sujetov je okrem iného ubúdanie čarodejnosti (zázračnosti) v prospech reálnych situácií, často aj s humoristickou dikciou.

4 Zo sujetu ako taxonomického kritéria vychádza väčšina zostavovatelov rozprávkových súpisov. Sujet v kontexte ludových rozprávok predstavuje samostatnú príbehovú jednotku s výraznými motivickými dominantami. Počas vývoja ludovej rozprávky sa sujety ustálili natol'ko, že nadobudli invariantnú vnútornú štruktúru s možnostou vonkajškových variácií. Sujet $\mathrm{v}$ tomto zmysle môže stát samostatne alebo sa môže kombinovat’ s ostatnými sujetmi v zložitejších príbehových celkoch. pojených archetypálnych znakov; takéto štruktúry nazývame v cassirerovskom duchu symbolickými formami.

Agrárny kultúrny komplex je vo svojom spirituálnom základe založený na ženskom duchovnom princípe. Matku zem, vel'kú živitelku rolníkov, považujeme za jeho najvýraznejší symbol. Jej rozprávkovou personifikáciou je striga, baba, ježibaba, bosorka, ako aj ich neskoršie realistickejšie modifikácie. Táto čarodejná postava $\mathrm{v}$ sebe nesie symboliku ženských predkov (spojenú s polnými, hospodárskymi a domácimi magickými úkonmi), je prepojená s vegetačnou sférou, cyklickostou, plodivostou a prejavuje sa ambivalentnou prírodnou kratofaniou. $\mathrm{V}$ najčistejšej podobe je $\mathrm{v}$ rozprávke spojená so zemou a podzemím, má silu oživovat’ a je vládkyňou smrti. V rozprávke Vintalko čítame opis strigy, matky krála celého sveta: „Tak ten má jednu mater, tá každô poludnie príde sem, jednu gambu zapne do zeme a druhú do neba a ja jej toto stádo musím do úst hnat." (Dobšinský 1958a, 232). Táto agrárna bohyňa života a smrti má syna - draka (hada). Zatial’ čo bohyňa predstavuje základnú abstraktnú silu v duchovnom svete, drak je vonkajškovou manifestáciou tejto sily, ktorá má $\mathrm{k}$ dispozícii matériu celého sveta, jeho monštruózne telo je metaforou substancie kozmu. V statickom póle jeho jestvovania je prepojený s podzemím, vodstvom a obnovou života, $v$ dynamickej podobe predstavuje deštruktívne, nespútané sily prírody. V agrárnych duchovných predstavách sídli v záhrobí, často je aj jeho zvrchovaným pánom. Ako taký stráži najväčší chtonický poklad: tajomstvo večného, obnovujúceho sa života. S drakom sa spája ešte jedna relevantná paralela s rituálmi a mýtmi jednoduchých pestovatelov - obetovanie panny komunitou. Rozprávkový sujet princezná obetovaná drakovi... je natolko rozšírený, že mu Jiří Polívka venoval samostatný zberatel'ský okruh (1923, 161-262), pravda, s dodatkom v názve ... a neznámy osloboditel', ten je už však zaodený do symbolických foriem nomádskeho kultúrneho komplexu.

2. Diachronická analýza nomádskeho kultúrneho komplexu má oproti agrárnym kultúram vel'kú nevýhodu, nezanecháva totiž po sebe výraznú materiálnu stopu. $\mathrm{Z}$ archeologického hladiska by sa mohlo zdat', že nomádske kultúry nezohrali dôležitú úlohu pri utváraní duchovného dedičstva ludstva, pravda je však opačná. Ich duchovná kultúra je v špecifickej pozícii, jej efemérnost' spôsobuje fakt, že je prevažne slovesná, vo svojej najvlastnejšej podobe orálna. Ako taká má výrazný abstraktno-symbolický charakter, a to aj mimo svojho slovesného rozmeru. Mobilný spôsob života nomádov nedovoloval rozvinutie materiálnej kultúry, jej estetický potenciál sa preto dominantne kreoval v príbehovom a piesňovom umení. Všeobecne možno konštatovat', že nomádske kultúry majú tendenciu k zakonzervovaniu kultúrneho modus vivendi, čo vidno najmä v porovnaní s agrárnymi kultúrami, ktoré podliehajú rýchlejšej kultúrnej zmene. Sila duchovného étosu nomádskych kultúr sa objavila všade tam, kde sa konfrontovali s agrárnou kultúrou. Príkladov takýchto stretov v Eurázii je viacero, nie sú však neobmedzené, preto nám dávajú indíciu, kde hladat sujetové jadrá sledovaných rozprávkových príbehov. Uved'me len niektoré príklady z odlišných etnických okruhov, ktoré pripadajú do úvahy: 
Koncom druhého tisícročia p. n. l. vstúpili do sveta rajských záhrad Mezopotámie kočovní Hebreji, pastieri oviec a kôz. Usadili sa, osvojili si znalost' (alfabetického) písma a zanechali po sebe jednu $\mathrm{z}$ najvplyvnejších písomných pamiatok sveta. To, čo čítame v Genezis, nepochybne obsahuje mytologickú látku domácej kanaánskej agrárnej kultúry. V čom však vidíme podstatný rozdiel, je hodnotové prispôsobenie vlastnému vnímaniu sveta, ktoré je $\mathrm{v}$ mnohom opačné. To, čo na seba v mezopotámskom mýte viazalo najvyššie hodnoty - had a bohyňa, a to, čo bolo v rámci jemnej ženskej komplementárnosti len doplňované mužským princípom, osnované okolo mystéria stromu života (a poznania), je tu obrátené. Patriarchálna kultúra nomádov vniesla do symbolických foriem rajských záhrad nový poriadok.

Podobnú zrážku vidíme pri vpáde árijských kmeňov do Indie. Kultúrny vplyv bojovných pastierov dobytka bol ešte intenzívnejší. Podobne ako inde, kde došlo k obdobným stretom, je $\mathrm{v}$ mytologickej látke postinduského obdobia zachytený konflikt dvoch svetonázorov. V najstaršej písomnej pamiatke védskej Indie - Rigvédach - čítame o Indrovi a jeho strete $s$ Vritrom, prvotným hadom a vládcom podzemia, ktorý spútava vody. Jeho matka Danu, v primárnom význame vnímaná ako božská matka, je spájaná s vodami padajúcimi na zem a následne s riekami. Obaja sú potom stotožňovaní s kravou a telatom, ktoré vel'ký pastier Indra zabíja (Hymnus XXXII. Indra).

Aj ked' nomádsky spôsob života Praindoeurópanov s typickou atmosférickou teogóniou a mytológiou plnou súbojov s drakmi a démonickými ženskými bytostami vyzerá pri identifikácii pôvodu sledovaného príbehovo-kultúrneho konfliktu nádejne, rad faktov svedčí skôr proti. V rozprávkach nenachádzame trojfunkčnú štruktúru indoeurópskej ideológie (Dumézil, 1997), podobne sa nevyskytuje ani náznak po kulte boha blesku a hromu, ako ho sledujeme vo všetkých zaznamenaných indoeurópskych národných mytológiách. Poslednou výhradou je pomerne častá prítomnost' hrdiniek v rozprávkach, čo nezodpovedá klasickým predstavám o mužskej vodcovskej funkcii (svetskej a duchovnej) v indoeurópskej spoločenskej hierarchii.

$\mathrm{V}$ predpokladanom období formovania sa symbolických foriem rozprávok však nájdeme aj iný mohutný kultúrny pohyb. V stepnej oblasti Strednej Ázie existoval (a stále rozptýlene existuje) zväz altajských národov, ktoré okrem jazykovej príbuznosti spájal aj nomádsko-pastiersky spôsob života. Z predpokladaného spoločného územia medzi Uralom a Altajom sa postupne rozšírili do celej ázijskej stepi a severne od Číny na celé východné územie terajšieho Ruska až po pobrežia Severného ladového oceánu. Nomádsky spôsob života týchto etník sa stáročia nemenil a ich plná sila sa v dejinách Eurázie vo vel'kých regionálnych kontaktoch prejavila niekolkokrát. ${ }^{5}$ Všeobecne možno konštatovat', že

5 Eurázia prežila najväčší nomádsky pohyb v 13. storočí n. l., ked' Mongoli vytvorili ohromné impérium siahajúce od Japonského mora po východné hranice Nemecka a na severovýchodnej osi zaberalo územie od Severného ladového oceánu až po Perzský záliv. uralskoaltajská kultúrna oblast' si spomedzi nomádskych kultúr zachovala najčistejšiu podobu nebeskej afinity, okrem iného vyznačujúcu sa aj nezúžením nebeského sakrálneho priestoru na prejav boha bleskov a búrky a tiež udržiavaním odstupu od stvoreného sveta - od sveta ludí. Uranovské božstvá týchto etník si zachovávajú zvrchovanú moc nad svetom a vševedúcností; sídlia $v$ najvyššom nebi, kde na vrchole posvätnej hory alebo v zlatom žiariacom paláci pod Polárkou stojí zlatý trón. Najvyšší boh má v pôvodných predstavách množstvo detí a blízkych oddaných služobníkov, ktorí obývajú nižšie nebeské sféry. S týmito bytostami sa stretáva šaman pri svojom extatickom výstupe do neba. Aj uralskoaltajská kultúrna oblast' asimilovala do svojho naratívu duchovné predstavy podrobených agrárnych kultúr, a to všade tam, kde pôsobila trvalo. Záznam tejto konfrontačne ladenej duchovnej akulturácie pravdepodobne čítame $\mathrm{v}$ niektorých typoch eurázijskej ludovej rozprávky prichádzajúcej k nám zo Strednej Ázie.

Nebeská sféra má v sledovaných rozprávkových príbehoch pozitívnu hodnotu. Personifikované slnko, mesiac, vietor a hviezdy (večernica a zornička) a od nich odvádzané javy a bytosti sa tešia v príbehoch najvyššej autorite. Hrdina a hrdinka si k nim idú po radu a po pomoc. Kardinálnym uranovským symbolom je slnko. V ceste za poznaním sa na tretej - hodnotovo najvyššej - gradačnej pozícii objavujú vedla seba najčastejšie slnko a vietor. So slnkom, mesiacom a vetrom sa hrdina nemôže zhovárat ako rovný s rovným; ako sprostredkovatel' slúži ich matka, menej často dištanciu naznačuje vel'ká vzdialenost’ medzi rozprávajúcimi, krátky moment stretnutia alebo iná forma nedostupnosti. Vietor má prepojenie na d’alšie atmosférické javy, na sklený vrch (zámok) a krála havranov. V jednej z variácií príbehu Ludojedi je „starý“ zobrazený ako Vietor, ktorý chodí sušit šaty na sklenený zámok (Dobšinský 1958a, 239). Sklený vrch sám predstavuje vzdušný (atmosférický) priestor, je priehladný, nedá sa naň vystúpit a na jeho vrchole sú citróny, zlatá krajina alebo iná metafora slnka. Slnko ako bytost' nikdy nevystupuje v pozícii nepriatela hrdinu. To isté platí pre mesiac a hviezdy. Solárny princíp má svoj vlastný okruh symbolov. Zo zvierat je so slnkom najviac spájaný kôñ je hlavným nadprirodzeným spojencom hrdinu. Podla Vladimíra J. Proppa je kôň (tátošík) univerzálnym pomocníkom, ktorý nemá v rozprávke konkurenta $(1999,72)$. Bohato zastúpeným typom príbehu v slovenských rozprávkach je sujet s ukradnutým slncovým koňom.

Všetky sledované čarodejné rozprávky si vo svojom základe zachovávajú antagonizmus medzi uranovskými a telurickými symbolickými formami. Tie sú viditelné najmä v príbehových konfliktoch. Pre agrárne symbolické formy je vymedzená sféra negatívnych hodnôt, naopak, nomádskym symbolickým formám je ponechaný pozitívny rozmer. Nie je náhoda, že $\mathrm{v}$ dramatickom jadre príbehu sú najškodlivejšími postavami ženské nadprirodzené bytosti. Ich škodcovská funkcia je nadradená aj takej rozprávkovej postave, akou je drak. Ak sa $\mathrm{v}$ jednom príbehu objaví ježibaba (baba, striga) aj drak (had), drak je jej vo všetkom podriadený, najčastejšie je to vyjadrené príbuzenskou hierarchiou. Pomenovanie ježibaba, podobne 
ako ruské babajaga, znamená matku hadov. Aj ked' je to práve hrdina/hrdinka, ktorí sú nositelmi najvyšších hodnôt a stoja proti démonickým bytostiam, nemôžeme ich ontologicky priradit pod uranovsko-solárne sféry, ako to urobili bádatelia mytologickej školy, ale musíme ich považovat’ predovšetkým za ludí.

3. Reprezentanti duchovna v nomádskych kultúrnych komplexoch sú vyvolení jedinci, majúci preukázatelné magické nadanie. Ich spiritualita má charakter riadenej individuálnej skúsenosti. Tento duchovný systém $\mathrm{v}$ pôvodných nomádskych kultúrach zodpovedá šamanizmu. Všeobecne ho môžeme považovat za celosvetovo rozšírený religiózno-kultúrny fenomén založený na extatickom stave duchovne nadaného jedinca, ktorý sa exteriorizuje „vystúpením na nebesia alebo zostúpením do podsvetia“ (Eliade 1972, 499). Pre nás je dôležitý pohlad na eurázijský šamanizmus: Šaman je v ňom „osoba mužského a ženského pohlavia, ktorá je schopná na základe výcviku či duchovného nadania pôsobit ako prostredník medzi členmi spoločenskej skupiny a nadprirodzenými silami (...). Tranz je predzvestou príchodu strážnych duchov. (...) Vzlety šamanovej duše môžu obsahovat' vyhladávanie stratených duší, prenos duše zomrelého do ríše mŕtvych a výzvednú výpravu do miest $\mathrm{v}$ tomto alebo druhom svete alebo návštevu vysoko postavených nadprirodzených bytostí, ktoré majú moc nad osudom a blahobytom ludí." (Hultkrantz 1993, 6).

$\mathrm{V}$ súlade $\mathrm{s}$ magickým svetonázorom sa čarodejné rozprávky vymedzujú ako žánre práve magickostou. Zázračnost' je $\mathrm{v}$ nich spojená $\mathrm{s}$ vierou $\mathrm{v}$ existenciu kauzálnosti medzi javmi na základe ich vonkajškovej podobnosti a dotyku. Oba tieto magické princípy, ktoré pomenoval už Frazer (1994, 18-46), sledujeme v celej semiotickej štruktúre rozprávok. Markantným príkladom princípu podobnosti je premena predmetov na prírodné javy: „Bol by ich istotne skoro dolapil, ale šuhaj zahodil hrebeň a povedal: ,Hora, hora, urob sa mi taká, ako tento hrebeň!' I hned' bolo tak. Pred ním pekná zelená lúka a za ním hora hustá ako hrebeň. “(Dobšinský 1958a, 167). Princíp dotyku je najčastejšie stvárnený v synekdochickej podobe: „,Prisnilo sa mi, že by to dobre bolo vediet', ako by mňa dáky človek, ak by sa predsa sem dostal, odtialto odviest mohol, čo by si mu ty neubližil?' ,Hm!' povedá drak, ,to ti vediet' daromnô, lebo to sa tak priam nestane. Ten človek by musel akú takú márnu vec zo mña mat' a tento môj zámok tamto tým prútom tri razy šibnút', aby sa jeho brány zavreli. “' (Dobšinský 1958a, 95).

Skutočným predobrazom hrdinu $\mathrm{v}$ rozprávkach je teda čarodejník či šaman. Absolvované súboje, prestáte skúšky by hrdina nezvládol bez magického pôsobenia. Súvislost' s hrdinom ako čarodejníkom si všimol aj literárny vedec Viliam Marčok: „Preto ak existoval nejaký prototyp príbehov čarodejných rozprávok, muselo ním byt konanie čarodejníka“ (1978, 108). Podobný postreh vyslovil aj V. J. Propp: „Keby sme zhromaždili rozprávanie šamanov o ich putovaní pre dušu na druhý svet, o tých, ktorí im pri tom pomáhali, o spôsoboch premiestňovania atd', a porovnali tieto príbehy s putovaním alebo s letom rozprávkového hrdinu, zistili by sme medzi nimi zhodu, ktorá neplatí len pre jednotlivé prvky, ale pre celok.“ $(1999,75)$.
„Medzikultúrne vzaté, $\mathrm{k}$ vyvoleniu šamana často dochádza v puberte, aj ked' kandidát môže prejavovat' tendencie naznačujúce šamanské schopnosti už skôr" (DuBois 2011, 86). Ludové čarodejné rozprávky v mnohom pripomínajú rituály iniciácie dospelosti, sú plné liminárnej symboliky (van Gennep 1996; Turner 2004). Je to všeobecné zistenie, ktoré zhodne potvrdzujú antropológovia, etnológovia i literárni vedci. S týmto tvrdením súhlasíme ako s východiskovým zistením. Antropologické prístupy nám však dovolujú toto východisko viac konkretizovat'. Napojením na predchádzajúce poznatky vidíme $\mathrm{v}$ analyzovaných príbehoch iniciáciu mladého adepta na šamana.

Cesta - ako dôležitý symbol nomádskeho kultúrneho komplexu - sa v rozprávkach začína odchodom hrdinu z domova. Odlúčenie je podmienkou začatia individuálnej duchovnej cesty. Niektoré nomádske tradície považujú samotu spojenú $s$ askézou (odopieraním si potravy či pohodlia) spolu s rizikom prírodného nebezpečenstva za nutnost' začatia duchovnej cesty a zároveň za prvú v rade skúšok. Cesta má však aj druhý význam, znamená vnútornú cestu šamana do sveta psyché alebo - ako si to exteriorizujú duchovné tradície do spirituálnych svetov. Rozdiel medzi skutočnou cestou, ktorá slúži na odlúčenie šamana, a medzi duchovnou cestou je zachytený konvenčnými liminárnymi motívmi, ako je spánok alebo odpočinutie si pod stromom.

Strom má v šamanských tradíciách dôležité miesto, predstavuje vstup (rebrík) do nebeského sveta. M. Eliade opisuje rituály zasvätenia uralskoaltajských šamanov pri vystupovaní na strom (niekedy na stîp) siahajúci do neba a stojaci uprostred sveta. Tento strom má sedem (až devät') stupňov, pričom každý symbolizuje astrologické dominanty (najvyšší stupeň patrí slnku). Obrad obsahuje aj let na duši obetovaného koňa (nebeské bytosti si o strom sveta priväzujú svoje kone); je to najvyššia a najrozšírenejšia uralskoaltajská obet' (1972). Antropologička Maria A. Czaplicka uvádza výpovede domorodých svedkov, podla ktorých sa sibírski šamani vznášali na dušiach svojich koní nad oblaky do neba, aby tam nachádzali stratené duše mŕtvych alebo navštevovali bohov (1991, 238). V rozprávke o Jankovi Gondášikovi a zlatej paničke čítame o „dreve ocelovom“, ktorého „vrch dosahoval hen $k$ nebu“: "Tak schytil balty na seba a zatínal do toho stromu; jednu baltu vytrhol a za druhú sa chytil; tak šiel po tom strome hore za tri mesiace aj za tri dni, čo nikde nevidel haluz. Už mu bolo zle dolu ist', tak sa len tahor poberal. Tak šiel zas za devät' dní. Ukázalo sa mu jedno jablko, maličké ako jedna hrst'. Tak sa dobre ponáhlal. A to bol na tom strome jeden kaštiel.' Zlatý gánok bol okolo kaštiela. Ked' prišiel ku kaštielu, tak sa chytil a vyskočil na ten gánok. Vtom proti nemu vyskočila jedna zlatá dievka: ,Hop, Janko, ja som tvoja, a ty si môj!' Zabavil sa tam za tri dni. Po troch dňoch povedal: ,Hej, pani princezná, ja nemôžem tu byt', ja musím vrch nájst' tomuto stromu. ',Hej, Janko, dobre ti je tu, nejdi d'alej; čo ti duša žiada, to všetko máš tu. ',To mňa neuspokojí, ja musím tájst' tomuto stromu vrch hladat." ,Ej, nejdi, prosím t'a. Dost' si zaslúžil, kým si zo zeme hor vyšiel, ved' tu ani vtáčik nevyletí. 'Nemohla mu zbránit', aby nešiel." (Czambel 1959a, 29-30). Podobne sa udialo aj v nasledujú- 
cich dvoch gradačných stupňoch, po ktorých sa Janko Gondášik ${ }^{6}$ dostáva na druhý svet.

Kameň naproti tomu slúži ako vstup do podsvetných sfér. Spojenie strom-nebesá a kameň-podsvetie je z hladiska substanciálnosti javov zrejmé, ich neskoršie zamenenie na princípe spoločnej funkcie spirituálnej brány nie je nič výnimočné. $\mathrm{V}$ nebeskom svete (tam, kde sa hrdina dostane po strome) sa potom môže odohrat další sujet, typický pre okruhy s drakom a podsvetím.

Menej viditelný prechod do druhého sveta je pri priestore hory (lesa). Tá má v rozprávkach podobný význam (v zmysle druhého sveta) ako nebeský a podzemný svet. Je to priestor zázračna, vykazujúci znaky nereálnosti. Hora nie je primárnym životným priestorom nomádskych spoločenstiev, môže preto dobre poslúžit ako metafora tajomného, mystického sveta. V ludových príbehoch Uraloaltajcov smeruje cesta mŕtvych do hôr. $\mathrm{V}$ rámci iniciačných skúšok prenikajú hrdinovia do druhého sveta cez jaskyňu, ktorá je na vrchole hory. Podobne v ich náboženských predstavách prebieha šamanova cesta do podsvetia ako výstup na rad velmi vysokých vrcholov hory (Eliade 1972).

Spirituálny svet má vlastnú ontológiu a zákonitosti, nie je však nepodobný ludskému svetu, spája ho s ním empirický životný „materiál“, základné prvky, z ktorých je zložený aj druhý svet. Do spirituálneho sveta majú zo živých ludí prístup iba duše šamanov. $Z$ troch kamarátov môže $\mathrm{v}$ rozprávke do podsvetia zostúpit iba Lomidrevo a iba on si dokáže podrobit démonického sprievodcu - Laktibradu. Spirituálne svety sú obývané neludskými bytostami a dušami mŕtvych. Ak uvažujeme o hypotetických stupňoch vývoja duchovných predstáv - tak ako to robili evolucionistickí antropológovia - úroveň predstáv, ktoré sa nám prezentujú $\mathrm{v}$ našich príbehoch, sú na stupni démonolatrie. Šamanova duša sa svojou magickou silou a dôvtipom môže niektorým obyvatelom spirituálneho sveta rovnat', dokonca si ich môže naklonit' alebo podmanit,, či nad nimi vyhrat v súboji. Šamanovi duchovní pomocníci majú najčastejšie podobu totemického nomádskeho zvieratá. Čarodejnost zvieracieho pomocníka v rozprávkach sa prejavuje v spirituálnom svete, pri návrate do sveta ludí sa - podobne ako jeho pán - mení na obyčajné zviera.

Hrdina absolvuje aj špecifické cesty za velkými duchmi. Tieto bytosti nemôžeme dat na rovnakú úroveň ako hrdinových (totemických či démonických) pomocníkov. Cesty za slnkom, mesiacom a vetrom sme už čiastočne opísali, ich moc presahuje hrdinu aj nižších duchov, sú mu dokonca nebezpeční (nie nepriatel'skí) a nemôže sa $\mathrm{k}$ nim približiti. Ich rada a prípadná pomoc je cenená najviac. Odkrýva sa nám tu dalšia funkcia šamana, ktorou je veštenie a získavanie informácií nadprirodzenou cestou: „,Počuj, Janík! Ked'ty chceš moju dievku mat', idi skôr zpýtat'sa Slnca, prečo nesvieti a nehreje v noci ako vo dne, a Mesiac, prečo nesvieti vo dne ako v noci a nehreje. Ked' jim donesieš vývod o tom, dám ti moju jedinicu i všetko bohatstvo. (...) Ked’im riekol, že ide $k$ Slncu a Mesiacu, prosil ho gazda, aby nezapomnel opýtat'sa Slnca, prečo jim tam na dvore najpeknej-

6 Gondášik (gondáš z madarčiny) je pastier svín. šia hruška už od rokov nerodí, čo predtým také zdravé ovocie rodievala, že až omládal, kto z neho jedol. Janko mu to vdačne prislúbil a ráno šiel dalej. Šiel zase cez hory doly, rovne a lesy, až prišiel do jednej dediny, kde bola velká tvŕdza o vodu. Ked'tu počuli, že Janko ide $k$ Slncu a k Mesiacu, prosili ho, aby vyzpýtal sa Slnca, prečo jich jediná studña vody im nedáva, ked’ predtým pre všetkých postačovala. Janko slúbil, že ked' jedno, vykoná aj druhé a šiel zase d’alej." (Dobšinský 1906c, 27). Funkcia veštca alebo vedomca je zachytená priamo $\mathrm{v}$ princípe nomen omen viacerých postáv. Za svoju službu dostáva hrdina odmenu, $\mathrm{v}$ rozvitejších príbehoch sa aj sám podiela na odstránení príčin neštastia. Ak sa k velkým duchom vydá na cestu nesprávna osoba, jej smrt je istá. Nemôžeme ich preto považovat výlučne za bytosti dobra, tak ako sa formujú $\mathrm{v}$ neskorších teistických predstavách. Ich hierarchia je daná najmä magickou silou. Pre čarodejníka je vstup do spirituálneho sveta a kontakt s jeho bytosłami vždy potenciálne nebezpečný.

Už samotné prekročenie hranice spirituálneho sveta vyvoláva útok strážcu prahu. Podla Josepha J. Campbella patrí strážca prahu $\mathrm{k}$ archetypálnym prvkom monomýtu; hrdina „pristupuje k prahu, za ktorým čaká dobrodružstvo. Tam sa stretáva s tieňovou postavou strážiacou vchod. Hrdina môže túto silu porazit', alebo s ňou vyjst po dobrom, a živý vstupuje do královstva temnoty. " $(2000,221-222)$. V sledovaných príbehoch majú hrdinovi nepriatelia vyhradené symbolické formy, identifikovali sme dva základné symboly: Ježibabu a draka. Hrdina sa s nimi alebo ich substitúciami stretáva v magickom súboji. Konflikt sa nemusí končit porazením nepriatela na smrt, niekedy si ho hrdina podrobuje a zotročuje, v neskorších súbojoch si ho potom privoláva na pomoc. „Vtedy uchytil Vintalko svoju šablu a stínal mu hlavy jednu za druhou. Ale ked' mu už na ostatnú mieril, tu sa začal milý drak prosit: ,Odpust mi, Vintalko, daruj mi život, budem ti ešte dakedy na dobrej pomoci.' Vintalko poslúchol; poodtínané hlavy mu naspät pokládol, ktoré sa hned' prirástli. Drak mu zadakoval a uchytil svoj necht $z$ palca na pravej nohe, odrapil ho a dal Vintalkovi: ,Tu máš tento necht. Ked' budeš dakde v dákom nebezpečenstve, len si nañ a na mña pomysli: Naraz ti príde na pomoc sedemdesiat regimentov drakov takých ako som ja, s deviatimi hlavami. "(Dobšinský 1958a, 230).

Osobitým problémom je rozlíšenie medzi ludskými a nadprirodzenými postavami. Konštatovali sme, že predobrazom hrdinu v rozprávkach je človek (na rozdiel od niektorých mýtov, kde môžu byt hrdinami božstvá či personifikované transcendentné sily). Hrdina však nie je jediným človekom, jeho súperom môže byt rovnako nadaný jedinec. V slovenských rozprávkach je ním napr. černokñažník (naproti tomu sú strigôn a ježibábel' - obaja odvodení od ženských démonických bytostí strigy a ježibaby - neludské postavy). V nomádskych spoločenstvách existuje rivalita konkurenčných šamanov v rámci jednej komunity. Šamani bojujú o prestíž a snažia sa svojho súpera porazit v magickom súboji. Najčastejšia forma súboja je premieňanie sa na zvieratá a veci, ktoré majú schopnost' vzájomne sa zničit. O podobnom type súbojov čítame aj v čarodejných rozprávkach. V príbehu Černokňažník odvádza chudobný človek svojho syna do služby: „Idú, idú horami, 
nájdu tam jedného čierneho chlapa na skale sediet’ a knihy čitat'. A to bol hladteže - černokňažník. ${ }^{\text {7 }}$ Hrdina sa vyučí jeho remeslu a pomocou kúziel od neho uteká. S otcom sa potom živia tak, že sa hrdina premieňa na zvieratá, ktoré otec predáva na trhu. Černokňažník to zistí, kúpi a následne unesie koňa, na ktorého sa hrdina premenil. Ked' sa ho chystá potrestat' kutím žeravých podkov zaživa, hrdina osloví prizerajúceho sa chlapca: „Chlapče, zosnímže ty tento kantár zo mřa. 'Chlapec tak urobil a náš kôň sa premenil skoro na holuba a letel preč. Ako to černokñažník spozoroval, hned'sa urobil na jastraba a pustil sa za ním. Leteli, kým leteli oba, až veru už jastrab mal dochytit' holuba. Bola tam jedna královská záhrada. Po nej sa prechodila smutná, zamyslená králova dcéra, že jej otec na smrt' bol chorý a nik sa nenašiel, kto by ho bol vyliečil. Len tu odrazu vidí pred sebou krásneho šuhaja, ktorý ju pekne začal prosit, že či by ho ako prsteň na svoj prst neprijala.(...) Tu ako králova dcéra ten prsteň zosnímala, odpadol jej voliakosi na zem a hned'sa na proso rozsypal. Ako to černokňažník videl, spravil sa na kohúta a začal to proso zobat'. Už ho bol všetko pozobal, kremä jedno zrnce volakde sa do jednej škárky zakotúlalo, to nemohol nijak von dostat'. Urobil sa na my̌̌, že ho tak von dostane. Ale milô zrnce sa premenilo na kocúra, ten myš uchytil a na márne kusy rozdriapal - bolo po černokňažníkovi." (Dobšinský 1958a, 118-121). V živých šamanských tradíciách sú takéto príbehy rýchlych premien šamanov na veci a zvieratá, ktoré sa vzájomne ničia, vel'mi časté (DuBois 2011, 253-254).

Ďalším ustáleným prvkom v šamanskej tradícii je deštrukcia tela a jeho obnova (oživenie) v novej, dokonalejšej podobe. V rozprávke Chorý král o tom čítame: „Už-už hriva tátošova bola v bráne: drak skočí, pochytí Janka a na drobné kúsky ho poseká. Vtom priletia tri havrany čierne ako žúžol', a jeden začne z mäsa Jankovho zobat. ,Nezobaj, 'povie najstarší, , ale zbieraj, to je ten, ktorého náš otec poslal pre čerešne. 'Hned’ počali mäso zbierat' a skladat' a v okamžení stál Janko pred nimi sedem ráz krajši ako predtým." (Dobšinský 1958a, 104). Tú istú myšlienku smrti a znovuzrodenia do nového vyššieho stavu treba hladat aj za menej komplexnými motívmi, napr. v odrezanom mäse z Lomidrevovej nohy či v mrzačení hrdiniek. Všetky časti tela sa hrdinom vrátia, často v novej zlatej podobe. Symbolika zlatej, najvzácnejšej farby, je dobre odvoditelná od solárneho kultu. Telo je v rozprávkach projekciou kvality hrdinovho vedomia a symbolickej formy kultúrneho významu. V rozprávke Dalajláma sledujeme jemnejšie odstupňovanie transformácie. Janík po vstupe do hustej hory stretne strigôňa, ku ktorému ide do služby. Strigôn - strážca prahu - mu zakáže vstup do druhej a tretej izby. „Šuhaj chytrý, otvorí dvere a tu vidi, ako tam zlato potokom tieklo; omočil do neho prst, naraz mu ostal zlatý'; ked” to strigôn zistí, rozhnevá sa na Janka, no neublíži mu. Zákaz poruší aj druhýkrát, ked’ vchádza do tretej izby „(...) a ako ju otvoril, tu vidí mnoho ludí jedných mŕtvych a druhých živých, ale sa žiaden z nich nemohol hýbat;

7 Kniha, tak ako sa vyskytuje v našich príbehoch, evidentne nahradila niektorý starší čarodejný predmet. Jej „používanie“ (teda neznalost toho ako kniha v skutočnosti „funguje“) prezrádza preliterárnu (respektíve negramotnú) spoločnost'. a stál tam $v$ kúte aj jeden sivý kôň. Tento priskočil $k$ šuhajovi a povedal mu: ,Janko! Vezmi tú mast'z police a popotieraj s ňou hrdlá týmto l'ud’om!' On vzal tú mast', a ako im radom hrdlá popotieral, tí mŕtvi naraz ožili a tí druhí sa začali hýbat. Tu mu všetci d’akovali, že ich zo zakliatia vyslobodil a naradovaní utekali von. A ten sivko zase sa ohlásil: ,Teraz chod', zamoč si vlasy $v$ zlatom potoku a vyber si čo najkrajšie šaty! ... Tam nájdeš aj jednu piśtalku a jeden prútik. To si skry a vezmi so sebou aj hrebeň, kremeň a ociel'ku. “ (Dobšinský 1958a, 166). Zlaté vlasy sú symbolom najvyššieho duchovného stupňa, potvrdenie vidíme aj $\mathrm{v}$ moci oživovat' mŕtvych, $\mathrm{v}$ schopnosti čarovat' (zmocnenie sa čarodejných predmetov), v získaní pomocníka zo spirituálneho sveta a v neposlednom rade v porazení strážcu prahu. V profánnom priestore hrdina svoje zlaté atribúty skrýva. Viditelné sú tak najmä v spirituálnom svete. Podobným symbolom je zlatá hviezda na prsiach a na čele. Absolutizáciou je zobrazenie hrdinu, ktorý je celý zo zlata, ako to čítame v explicite Zlatej podkovy, zlatého pera, zlatého vlasu: „Ked” mlieko najväčšmi vrelo, mal Janko do neho skočit. Ale tátoš na jedno dýchnutie všetku horúčost' z kotla do seba vtiahol. Šuhaj skočil dnu a hned'ostal celý zlatý." (Dobšinský 1958a, 73). Zlaté telo a jeho časti (najmä hlava) predstavujú univerzálny spirituálny prvok vyššieho duchovného stavu, spojeného so symbolikou solárneho princípu, teda všeobecne s nebeskou afinitou vyjadrenou archaicky $\mathrm{v}$ mikrokozme transformovaného ludského tela. Stačí si spomenút na vyobrazovania gloriol krestanských svätých alebo vyžarovanie indických svámí, aby sme si uvedomili rozsah tejto duchovnej predstavy. Zároveň je tu dobre viditel’ný rozdiel v estetickej transformácii metafyzických významov. Máme na mysli mieru markantnosti v takzvanom vysokom a ludovom umení. Ludová poetika, ktorá všeobecne neinklinuje $\mathrm{k}$ abstraktnému zobrazovaniu, používa pri vyjadrení vyššieho duchovného stavu zosilnenú telesnost?

4. Odpojením sa od duchovnej praxe začali rozprávky fungovat' ako svojbytné umelecké komunikáty, od tohto momentu podliehali kultúrnym substitúciám a prekrývaniam, estetickým štylizáciám, morálnym a náboženským cenzúram a $\mathrm{v}$ neposlednom rade editorským predstavám zberatelov. V konzervatívnom prostredí ludovej kultúry si však až do ich zapísania zachovali podstatné znaky pôvodných duchovných predstáv, ktoré, nech už je ich význam pre súčasníka akokolvek hmlistý, nevymizli ani v dynamických premenách oficiálnej umeleckej a duchovnej kultúry.

\section{PRAMENE}

Czambel, Samuel (1959a): Slovenské ludové rozprávky I. SVKL. Bratislava. [cit. 1. 1. 2021] dostupné online https://zlatyfond.sme.sk/dielo/903/ Czambel_Slovenske-ludove-rozpravky-I/1

Czambel, Samuel (1959b): Slovenské ludové rozprávky II. SVKL. Bratislava. [cit. 1. 1. 2021] dostupné online https://zlatyfond.sme.sk/dielo/904/ Czambel_Slovenske-ludove-rozpravky-II/1

Dobšinský, Pavol (1958a): Prostonárodné slovenské povesti I. Bratislava: SVKL. [cit. 1. 1. 2021] dostupné online http://zlatyfond.sme.sk/dielo/585/Dobsinsky_Prostonarodne-slovenske-povesti-Prvy-zvazok. 
Dobšinský, Pavol (1958b): Prostonárodné slovenské povesti II. Bratislava: SVKL. [cit. 1. 1. 2021] dostupné online http://zlatyfond.sme.sk/dielo/531/Dobsinsky_Prostonarodne-slovenske-povesti-Druhy-zvazok.

Dobšinský, Pavol (1958c): Prostonárodné slovenské povesti III. Bratislava: SVKL. [cit. 1. 1. 2021] dostupné online http://zlatyfond.sme.sk/dielo/389/Dobsinsky Prostonarodne-slovenske-povesti-Treti-zvazok.

Dobšinský, Pavol (1880a): Prostonárodnie slovenské povesti. Sošit 1. Turčian-sky Sv. Martin.

Dobšinský, Pavol (1880b): Prostonárodnie slovenské povesti. Sošit 2. Turčian-sky Sv. Martin.

Dobšinský, Pavol (1880c): Prostonárodnie slovenské povesti. Sošit 3. Turčian-sky Sv. Martin.

Dobšinský, Pavol (1881): Prostonárodnie slovenské povesti. Sošit 4. Turčian-sky Sv. Martin.

Dobšinský, Pavol (1906a): Prostonárodnie slovenské povesti. Sošit 5. (druhé vydanie) Turčiansky Sv. Martin.

Dobšinský, Pavol (1906b): Prostonárodnie slovenské povesti. Sošit 6. (druhé vydanie) Turčiansky Sv. Martin.

Dobšinský, Pavol (1906c): Prostonárodnie slovenské povesti. Sošit 7. (druhé vydanie) Turčiansky Sv. Martin.

Dobšinský, Pavol (1906d): Prostonárodnie slovenské povesti. Sošit 8. (druhé vydanie) Turčiansky Sv. Martin.

Kollár, Ján (1953): Národné spievanky I. Bratislava: SVKL.

Škultéty, August Horislav - Dobšinský, Pavol (1858/1861): Slovenské povesti. Vernaleken Oesterr. KVN, č. 30

\section{LITERATÚRA}

Campbell, Joseph John (2000): Tisíc tvář́ hrdiny : archetyp hrdiny v proménách věkư. Praha: Portál.

Czaplicka, A. Maria (1991): Aboriginal Siberia. A Study in Social Anthropology. Oxford: Clarendon Press.

DuBois, A. Thomas (2011): Úvod do šamanismu. Praha: Volvox globator.
Dumézil, Georges (1997): Mýty a bohové Indoevropanů. Praha: OIKOYMENH.

Eliade, Mircea (1972): Shamanism : Archaic Techniques of Ecstasy. Princeton: Princeton University Press

Frazer, James George (1994): Zlatá ratolest. Praha: Mladá fronta.

van Gennep, Arnold (1996): Přechodové rituály. Systematické studium rituálů. Praha: Nakladatelství Lidové noviny.

Hultkrantz, Ake (1993): Introductory Remarks on the Study of Shamanism. Shaman: An International Journal for Shamanistic Research, 1(1), 1993 3-14.

Marčok, Viliam (1978): O ludovej próze. Bratislava: Mladé letá

Polívka, Jiří (1923): Súpis slovenských rozprávok. Zv. prvý. Turčiansky Sv. Martin: Matica slovenská.

Propp, Vladimir Jakovlevič (1999): Morfologie pohádky a jiné studie. Jinočany: $\mathrm{H} \& \mathrm{H}$.

Šutor, Lukáš (2018): Ludové čarodejné rozprávky vo výskume klúčových osobností sociálnej a kultúrnej antropológie. Anthropologia Integra : Časopis pro obecnou antropologii a príbuzné obory, 2(9), 21-28.

Turner, Victor Witter (2004): Průběh rituálu. Brno: Computer Press.

\section{AUTOR}

Šutor, Lukáš (5. 11. 1982): Doktorské a doktorandské štúdia absolvoval v odboroch estetika a literárna veda. Vedecky sa zameriava na prepájanie kulturologických a umenovedných pohladov pri skúmaní ludovej slovesnosti a drámy. $\mathrm{Na}$ katedre slovakistiky, slovanských filológií a komunikácie FF UPJŠ v Košiciach vyučuje teóriu kultúry, semiotiku estetických objektov, ludovú slovesnost', antropológiu umenia, dejiny slovenskej literatúry a teóriu drámy. Výskumu ludovej čarodejnej rozprávky z kulturologickej perspektívy sa najvýraznejšie venoval ako vedúci projektu Genóm slovenskej ludovej čarodejnej rozprávky.

Kontakt: PhDr. Lukáš Šutor, PhD. email: lukas.sutor@upjs.sk 